\title{
A APROPRIAÇÃO DA ARS IMITANDI NAS COMÉDIAS DE LUDOVICO ARIOSTO E DE SÁ DE MIRANDA
}

\section{THE OWNERSHIP OF THE ARS IMITANDI IN LUDOVICO ARIOSTO'S AND SÁ DE MIRANDA'S COMEDIES}

\author{
Martha F. Maldonado Baena da Silva ${ }^{1}$
}

RESUMO: Este trabalho trata das aproximações no processo de "apropriação" da ars imitandi nas comédias de Ariosto e de Sá de Miranda. Ambos escreveram comédias nos moldes clássicos, retomando o modelo antigo, imitando-o e dele se apropriando. A questão da apropriação, aqui, diz respeito mais do que à de textos precedentes consagrados, à apropriação da técnica de reelaboração criativa desses textos (imitatio) para a composição de textos novos.

PALAVRAS-CHAVE: intertextualidade; imitatio; comédia clássica; Ariosto; Sá de Miranda.

ABSTRACT: This paper discuss the approaches on the process of "ownership" of the ars imitandi in the comedies written by Ariosto and Sá de Miranda. Both of them wrote comedies following the classic models, retaking the old pattern, imitating it as much as making it own. The question of the ownership, here, is about the creative rewriting technique (imitatio) to compose new texts more than the ownership of precedent and acclaimed ones.

KEYWORDS: intertextuality; imitatio; classic comedy; Ariosto; Sá de Miranda.

\section{Introdução}

As peças mirandinas Os Estrangeiros e Os Vilhalpandos são as primeiras em língua portuguesa a nos remeter de imediato às comédias da Antiguidade Clássica, tanto gregas como latinas. De Aristófanes e Menandro a Plauto e Terêncio, de Sêneca a Horácio, passando por variadas lembranças da poderosa Roma em citações e alusões, os textos vão levando o leitor àquele mundo antigo, de escravos e soldados, meretrizes e matronas, guerras e naufrágios, mas leva também ao gênero cômico mesmo, com suas expressões formulares e seus tipos cômicos, tratados na própria Antiguidade, respectivamente, por Aristóteles e por seu sucessor na escola peripatética, Teofrasto.

De tudo isso deriva a maior parte dos estudos desta pesquisadora. Temos investigado durante anos a influência das comédias aristofânicas sobre as de Menandro,

\footnotetext{
${ }^{1}$ Doutora em Filologia e Língua Portuguesa e Mestre em Literatura Portuguesa pela Universidade de São Paulo.
} 
a influência destas sobre as latinas, que viriam a ser modelo para grande parte dos autores que escreveram depois, especialmente para aqueles que compuseram no período renascentista do século XVI.

Nesse percurso, deparamo-nos com nomes importantes da literatura italiana, como Boccaccio, Maquiavel, Bibbiena e - em especial - Ludovico Ariosto, e suas importantes obras, tanto as consideradas maiores como as menores, e é nestas que se encaixam as comédias, os textos satíricos, além da poesia lírica.

Mas foi principalmente Ariosto quem concedeu a maior parte dos argumentos de que fizemos uso para desenvolver e defender nossos trabalhos e teses. Esse poeta italiano, que se pode considerar um dos mais perfeitos de todos os tempos (levando em conta - como sugere T. S. Eliot - a sua época, a maturidade de sua língua, a cultura da sociedade em que vivia e a densidade de sua obra) foi quem nos deu as mais largas bases para trabalhar.

Ariosto escreveu, em italiano, um dos poemas mais belos já escritos em qualquer língua: o épico Orlando Furioso. Escreveu ainda sátiras (são sete) em língua vernácula, seguindo o modelo da sátira horaciana, e também poesia lírica em latim (especialmente elegias e epitáfios) e em vernáculo. Além disso, foi autor de cinco comédias - La Cassaria, I Suppositi, II Negromante, Gli Studenti e La Lena -, todas em prosa e língua vulgar (algumas, mais tarde, foram reescritas em verso).

Duas das comédias ariosteas, especificamente I Suppositi e La Lena, são as que mais influenciaram Sá de Miranda. Deste poeta português, infelizmente, costuma-se saber somente, nas aulas de Literatura Portuguesa, que foi o introdutor do Classicismo em Portugal, que trouxe de sua vivência na Itália a "medida nova" - o soneto e formas clássicas de poesia - e pouco mais que isso, que ele teve alguns de seus poemas aqueles feitos na "medida velha" - incluídos no Cancioneiro Geral de Garcia de Resende.

Mas ambos, Ariosto e Sá de Miranda, escreveram comédias, e o fizeram nos moldes clássicos. Por conta desta retomada do modelo antigo, da imitação feita por ambos, este trabalho tratará das aproximações no processo de "apropriação" da ars imitandi nas comédias de Ariosto e de Sá de Miranda.

A questão da apropriação, aqui, diz respeito mais do que à de textos precedentes consagrados, à apropriação da técnica de reelaboração criativa desses textos para a composição de textos novos, textos tidos como inéditos.

A ars imitandi, a técnica de recriação literária utilizada pelos antigos romanos, foi também desenterrada, junto com uma imensa quantidade de textos, pelos humanistas e 
utilizada pelos poetas do Renascimento do século XVI de forma bastante semelhante àquela empregada pelos poetas latinos, apresentando, contudo, algumas peculiaridades.

\section{A arte de imitar}

É característica primeira da literatura clássica - que compreendemos como a literatura da Antiguidade Greco-Latina tanto quanto a do Classicismo - o ter como princípio de criação poética a apropriação intencional de textos precedentes, ou seja, o tomá-los como matéria exemplar.

Diz o professor Paulo Sérgio de Vasconcellos, em seu proveitoso livro Efeitos intertextuais na Eneida de Virgílio: "Por princípio, um poeta jamais partirá do nada, mas criará sempre a partir de outros textos modelares" (2002, p. 23-24).

Ora, o autor que compõe sob esse princípio faz reconhecer seus predecessores e também a tradição à qual se filia. Faz isso empregando fórmulas e convenções que caracterizam o gênero da obra (a comédia, a poesia épica etc.) e tomando por empréstimo versos, ou partes de versos (textos ou partes de textos), temas e conteúdos que já são conhecidos de um determinado público (SILVA, 2009, p. 41).

Essas partes de textos serão reproduzidas em um novo arranjo e em um novo contexto, num processo de recriação literária a que os romanos antigos denominaram imitatio. Tal processo permitiu a criação de praticamente toda uma literatura "em segundo grau", usando os termos de Gérard Genette (1982), como podemos observar na literatura latina.

A imitatio é, pois, a relação mimética que se estabelece entre uma obra literária e outra (ou outras) obra(s) literária(s). Essa relação, que foi fundamental para o desenvolvimento da rica literatura da Roma antiga, por diferentes razões e com certas peculiaridades, voltou a se impor como processo de criação poética entre os autores do Renascimento (SILVA, 2009, p. 41).

No caso da literatura latina, houve uma causa histórica para que ela se estabelecesse por esse meio, que não foi unicamente "sua dependência inicial da literatura grega". Como observa Vasconcellos, os romanos estreitaram o seu contato com a literatura grega no período helenístico, em que se praticava a atividade literária usandose amplamente as alusões, que são importantes recursos intertextuais, desenvolvendo com isso a "arte da intertextualidade" (1982, p. 23). Esta passava, assim, a fazer parte do fazer literário. 
Os poetas latinos, então, tomaram de empréstimo à cultura grega não somente suas formas e conteúdos, textos ou partes de textos, mas também um modo de compor que já os poetas helenísticos praticavam, aludindo a outros textos. E eles aperfeiçoaram a prática da alusão até a sofisticação alcançada por poetas como Virgílio e Horácio (SILVA, 2009, p. 42).

Naturalmente que aqui se está a tratar de uma literatura produzida dentro de uma cultura escrita, que se baseia no culto, no estudo e no conhecimento profundo de textos escritos que são tomados como exemplo e que, para chegar ao nível de sofisticação a que chegou, desenvolveu uma técnica de reelaboração criativa de textos considerados exemplares.

Essa técnica poética implicava o emprego de métodos de composição e de artifícios que promoviam o jogo intertextual, que podemos denominar, na expressão de Giorgio Pasquali, de "arte alusiva" (1951).

A alusão é o meio pelo qual o poeta evoca o texto precedente, além de ser matéria e instrumento a serviço do poeta na construção do texto novo.

No Renascimento, as causas que levaram à elaboração de uma literatura baseada na dos antigos são diferentes das que promoveram a literatura latina. A história é outra, o momento é de trazer de volta o homem para o centro das preocupações do próprio homem, destronando Deus do seu posto centralizador de todas as atenções.

O homem, ou a natureza humana, que é o tema clássico por excelência, por suas qualidades de eterno e universal, sobrepõe-se aos temas sacros, os temas religiosos, que dominaram as artes ao longo da Idade Média, voltando ao posto de tema central, como havia sido para a Antiguidade.

Evocar uma tradição poética é um dos princípios da imitatio. Praticar o jogo alusivo, outro. E, desde que o jogo intertextual que a imitatio promove passa a ser concebido como fundamento do processo da criação poética, toda uma literatura começa a ser construída com base na apropriação intencional de textos (SILVA, 2009, p. 443-44).

Desse modo, o jogo se transforma numa arte que regula e estabelece critérios para a composição literária e, mais que isso, que permite ao escritor imprimir sutilezas em seu fazer literário.

A realização dessa literatura implica, antes de tudo, nos termos de Russell, a "aceitação [...] da imitação como um elemento essencial em toda composição literária" (1979, p. 1). 
Contudo, essa aceitação não implica que a obra resulte numa cópia servil do modelo, nem exige que o poeta torne-se escravo do predecessor, ou sua obra será uma imitação "mal sucedida", de acordo com os princípios de Russell.

Ainda nas palavras desse autor, "o poeta não pode deixar de ser imitator; esta é sua condição inevitável", mas ele pode evitar "a adesão meticulosa a aspectos verbais e superficiais de seu modelo." (1979, p. 1).

A imitatio propõe ao poeta aprofundar-se no universo de significações do texto imitado, permitindo-lhe aperfeiçoar e até corrigir possíveis falhas do modelo, incorporando, assim, o conceito de aemulatio, que é a tentativa não só de igualar, mas de superar o modelo.

Os dois conceitos, imitatio e aemulatio, segundo Russell, sempre se complementam; o processo que eles denotam pode ser bem ou mal feito, e a diferença estará não em mais ou menos imitação ou mais ou menos emulação, mas na escolha do objeto, na profundidade do entendimento e no poder do poeta de se apossar do pensamento como seu próprio (1979, p. 10)

Para estabelecer critérios que definam como esse processo pode ser "bem sucedido", Russell, baseando-se em Longino, aponta cinco princípios - que foram revistos e comentados no trabalho citado de Paulo Sérgio de Vasconcellos, de quem nos valemos aqui da tradução (RUSSEL, 1979, p. 16; VASCONCELLOS, 1982, p. 36-39):

Princípio número 1: "O objeto deve ser digno de imitação".

Princípio número 2: "Deve-se reproduzir o espírito mais que a letra".

Princípio número 3: "A imitação deve ser tacitamente reconhecida, na compreensão de que o leitor informado reconhecerá e aprovará o empréstimo".

Princípio número 4: "O empréstimo deve se tornar algo próprio, pelo tratamento individual e assimilação a seu novo contexto e propósito".

E princípio número 5: "O imitador deve pensar de si mesmo que está competindo com seu modelo, ainda que saiba que não é capaz de superá-lo".

O próprio Russell admite que estes critérios são vagos, gerais e evidentes, mas também admite que eles não devem ser desprezados. Eles são, afinal, pistas para o começo da análise literária e sugestões para quem deseja fazer um julgamento crítico desse tipo de texto.

As observações que Vasconcellos apõe a cada um desses princípios, merecem ser mencionadas, pois esclarecem alguns pontos por demais vagos. Quanto ao primeiro princípio, se há dúvida do que seja um "objeto digno de imitação", ele diz que se trata, 
quase sempre, de uma homenagem ao precursor, mesmo quando as intenções são emulativas (p. 36). O professor esclarece, em nota de rodapé, que não é sempre uma homenagem, porque é possível, por exemplo, parodiar um verso ruim citando-o de alguma forma.

Enfim, o poeta insere-se numa tradição da qual não poderia prescindir e sua obra incorpora a dos seus (quase sempre) estimados precursores, aqueles que representam para ele paradigma de excelência, cuja "imitação" confere, por si só, a dignidade da autoridade dos patres (VASCONCELLOS, 1982, p. 37).

Quanto ao segundo princípio ("Deve-se reproduzir o espírito mais que a letra"), Vasconcellos julga ser esta a afirmação mais discutível das arroladas por Russell, por ser o jogo alusivo mais sutil e compreender ainda "o confronto estilístico com o modelo" (ibidem).

O terceiro princípio é mais claro. A alusão não pode passar despercebida ao leitor. A significação da alusão se completa no reconhecimento que dela faz o leitor, como veremos, mais adiante.

Também o quarto princípio é claro, mas parece melhor explicado nas termos de Vasconcellos (p. 38):

a operação intertextual jamais pode ser neutra, isto é, sempre cria novos sentidos que se sobrepõem ou contrastam com o do original reproduzido ou evocado. As formas de tratamento do material 'tomado emprestado' são múltiplas [...] e nem sequer podem ser catalogadas de modo esquemático em sua totalidade, pois as possibilidades do jogo intertextual são virtualmente ilimitadas.

Aemulatio é o conceito evocado no quinto princípio proposto por Russell e traz o sentido de competição: imitar para rivalizar com o modelo, buscando superá-lo.

Como vimos anteriormente, a aemulatio é parte do processo denominado imitatio. Não há aemulatio sem imitatio. Contudo, a imitação não pressupõe a emulação. Um autor pode aludir a um texto para parodiá-lo, como observou Vasconcellos sobre o primeiro princípio. Em suas palavras, "nem sempre a intenção é rivalizar com o modelo (corrijamos, pois, Russell), mas, por vezes, simplesmente provocar o riso" (p. 40).

Isso é o que observamos muitas vezes nas comédias, especialmente na fala dos escravos quando evocam um verso trágico, geralmente exagerando na expressão, em meio ao contexto cômico. Note-se que a paródia nem sempre tem em vista a destruição do modelo, mas sim, com a descontextualização, provocar o riso. É o que se vê, por exemplo, na Apocoloquintose de Sêneca. 
Em resumo, a imitatio bem sucedida é aquela em que a retomada de um texto por um autor - envolvendo ou não aemulatio - e o reconhecimento de tal retomada pelo leitor caminhem juntos.

Apropriar-se é tornar algo próprio, seu, e, sem o reconhecimento, o processo de apropriação não se completa.

É através da alusão que um autor busca apropriar-se do outro. A alusão faz referência a um texto e/ou contexto que se supõe presente no universo referencial do leitor e o jogo alusivo deve imprimir novos sentidos ao texto retomado dentro do contexto novo, sem que se perca o sentido anterior.

Assim é porque no jogo de sentidos que a alusão promove é que reside o prazer da leitura intertextual. O leitor deve reconhecer o sentido que a alusão tinha no contexto anterior e perceber o novo, no novo contexto, encerrando assim o processo de apropriação.

A título de exemplo de imitação bem sucedida, citaremos uma única passagem, retirada da comédia Pluto, de Aristófanes.

Lembremos antes, porém, que já as comédias de Menandro traziam, com frequência, alusões às peças de Aristófanes, além de aludir a tragédias, à mitologia e a lugares-comuns da épica e da literatura grega em geral.

Os empréstimos a autores consagrados, fossem de temas ou de versos inteiros, enriqueciam obras de todos os gêneros na Grécia. O próprio Aristófanes, antes de Menandro, já citava em suas comédias autores épicos, líricos e trágicos, colocando seus versos num contexto completamente diferente do original, o que promovia uma mudança de sentido de efeito cômico (ou seja, paródico). No exemplo a que nos referimos acima, fez isso com um verso da tragédia Telefo, de Eurípides, colocando esse verso na voz da personagem Pobreza da comédia Pluto.

Numa demonstração racional de que a pobreza tem mais valor do que a riqueza (entre outros motivos, porque a pobreza leva à virtude, enquanto a riqueza leva seus possuidores ao vício da avareza), a Pobreza tenta convencer o personagem Cremilo que tem Pluto, o deus da riqueza, hospedado em sua casa - a expulsá-lo e a deixá-la tomar o seu lugar. O hospedeiro do deus encerra o debate nesses termos:

Cre.: - ... vá para o inferno e não soltes mais palavras, porque não me convencerás, ainda que me hajas convencido.

E, a isso, responde a Pobreza, em tom trágico, evocando Eurípides: 
Pobreza: - "Ouvis o que disse, habitantes de Argos?" (s.d., p. 219)

Esse deslocamento do verso de seu contexto trágico, de tom elevado, para o da comédia, onde preside a ironia, promove, com o efeito intertextual, um estranhamento que provoca o riso.

$\mathrm{Na}$ literatura do Renascimento, o processo seria o mesmo; a técnica seria praticamente a mesma empregada pelos antigos, baseada na evocação num texto novo de textos precedentes, tendo a alusão como elemento de primeira necessidade para sua composição.

Neste momento, seria bom vermos definidos com maior precisão alguns conceitos aqui empregados. Para tanto, servir-nos-emos das formulações de Pasquali em sua "Arte Alusiva".

Para o filólogo italiano, "as imitações, o poeta pode desejar que escapem ao público", enquanto que "as alusões não produzem o efeito desejado senão sobre um leitor que se recorde claramente do texto ao qual se referem.” (1951, p. 11, grifos nossos).

Desse modo, entendemos que, para Pasquali, as imitações - quer o autor cite literalmente ou parafraseie um texto anterior - incluem o plágio, se o poeta não deseja o seu reconhecimento pelo leitor.

Neste caso, o jogo intertextual, se assim o podemos chamar, não produz outra significação que não a superficial - o texto que está por baixo do texto não transparece, ficando somente o próprio autor ciente de sua existência.

Já a alusão pressupõe o reconhecimento e a compreensão por parte do leitor do texto e do contexto que ela evoca, e deixa de fazer sentido se o leitor não a percebe.

Em ambos os casos, o leitor é predeterminado pelo autor: no primeiro caso, ele é um leitor que não conhece o texto imitado; no segundo, é o leitor capaz de reconhecê-lo.

Quanto às reminiscências, Pasquali diz que elas podem ser involuntárias, o que quer dizer que às vezes escrevemos coisas das quais nos lembramos sem perceber conscientemente que já as lemos em algum lugar - não há, então, a intenção de se apropriar do texto alheio.

Assim, a arte alusiva é um jogo que se estabelece entre três partes: autor, texto(s) e leitor. Nesse jogo, em que a alusão é o meio e a evocação é o fim, a intertextualidade seleciona os leitores, visto que é preciso detectar a alusão, o que não é tarefa fácil, e exige conhecimento extenso dos escritores da tradição cultural em que se insere o poeta 
ou prosador em foco, nos termos de Pasquali (ibidem), bem como a perspicácia de perceber sutilezas alusivas.

Mas não se pode dizer que se compreendeu a função de uma retomada de outro texto simplesmente quando se apontou a "fonte" ou "fontes" certas ou possíveis

Se, para a filologia, a "alusão é material que está objetivamente no texto", como diz Lowell Edmund (2001, p .43), para o jogo a três que Pasquali propõe, a alusão é algo subjetivo. Os significados que a alusão pode gerar só se integram ao texto se o leitor for capaz de identificá-los. As reminiscências, por sua vez, podem ser alusões que só existem da parte do leitor, provindas de seu universo de referências e não, efetivamente, do pensamento do autor. Combinadas com uma tendência a se buscar as fontes de tudo e a tudo imputar a intenção do autor, as reminiscências involuntárias podem resultar em má interpretação ou, ainda, em "superinterpretação" - para usar um termo apropriadamente empregado por Umberto Eco (2005) -, que supõe a intertextualidade a despeito da intenção.

\section{Ludovico Ariosto e Sá de Miranda}

Quanto ao processo de composição específico dos dois autores do Renascimento que investigamos, Ludovico Ariosto e Sá de Miranda, esse processo pressupõe a intenção desses autores de evocar textos consagrados da tradição clássica e de apropriar-se deles.

Nos textos dos quais tratamos, a alusão é necessária - lembrando aqui o sugestivo título de um livro de Maria Grazia Bonanno, L'allusione necessaria (1990) - e é indispensável para que o autor faça que seu texto evoque outro texto, que deve ser reconhecido pelo leitor. Mais que isso, ela deve ser também reconhecidamente bem colocada no novo contexto, ou seja, "bem sucedida".

Isso aponta para a também necessária existência de um leitor-modelo, um leitorintérprete, que é aquele sujeito culto, instruído na mesma tradição do autor, o leitor capaz de tomar parte no jogo intertextual praticado na imitatio, o que exclui aquele leitor a quem Umberto Eco denomina "intérprete paranóico" (2005, p. 57), aquele que se questiona o tempo todo quanto aos "motivos misteriosos" que levam um autor a "aludir" a determinado texto, não considerando jamais a involuntariedade de uma "retomada". 
Num caso como este, é a intentio lectoris (intenção do leitor) e não a intentio auctoris (a intenção do autor) que produz a evocação. A interpretação aí tomará o rumo que melhor servir aos propósitos interpretativos desse leitor (ECO, 2005).

Para analisar a composição das comédias de Ariosto, e depois a das comédias mirandinas, devemos pensar numa literatura que se constrói consciente e intencionalmente como "mosaico de citações" ${ }^{2}$, na perfeita expressão de Julia Kristeva para este caso. Lembremos que foi Kristeva quem cunhou o termo intertextualidade. ${ }^{3}$ Embora, de sua perspectiva, todo texto seja, por natureza, intertextual, independentemente da vontade do escritor.

Em contraposição à corrente russa, chefiada por Bakthin e disseminada por Kristeva, encontramos Conte, apostando nas alusões como figuras da elocução e na "função retórica da alusão como um aspecto do caráter sistemático da composição literária" (1996, p. 26) estando, assim, sob o controle do escritor.

Como as figuras da retórica, a alusão provoca "uma tensão entre o significado literal e o significado figurativo, entre o 'uerbum proprium' e o 'improprium'." (CONTE, 1996, p. 24). A tensão entre as duas realidades contrapostas cria a dimensão poética do texto.

Conte compara a alusão à metáfora, por serem ambas formas impróprias de expressão. Tanto a alusão como a metáfora existem em virtude de sua "duplicidade" semântica. Seu valor literário reside, como bem nota Conte, em sua capacidade de encerrar em tensão, dentro delas mesmas, o espaço vazio que se estende entre seu valor lexical e a imagem que elas obliquamente evocam (p. 53).

A comparação, embora muito interessante, desconsidera o fato de que a metáfora pode ser percebida por qualquer leitor, enquanto a alusão é uma "figura" que só um leitor "instruído" pode reconhecer como tal, como observa Edmunds (2001, p. 166).

A leitura que Conte propõe privilegia o texto, a construção do texto, as relações entre textos que se dão de forma consciente e técnica, tendo em mente a tradição dentro da qual o texto surge, uma tradição que ele define como "língua poética", "a projeção simultânea de modelos e códigos literários, [...] um sistema de regras e prescrições" (1996, p. 27).

\footnotetext{
${ }^{2}$ A expressão utilizada e tornada pública por Kristeva no artigo "Le mot, le dialogue et le roman", reimpresso

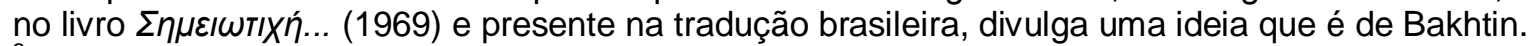

${ }^{3}$ Ver a interessante análise do trabalho de Kristeva que faz EDMUNDS, op. cit. 2001.
} 
Essa tradição, ou língua poética, prevê o que ele denomina "memória poética", que é ativada pela alusão, e pressupõe que autor e leitor estejam familiarizados com seus modelos e códigos - ou com o "modelo-código".

É esta a linha de pensamento que adotamos e que empregamos na análise dos textos escolhidos para este trabalho.

Notemos que, antes de a alusão poder ter o efeito desejado sobre o leitor, primeiramente ela deve ter exercido esse efeito sobre o poeta. Quanto mais facilmente o original puder ser reconhecido - quanto mais "citável" ele é (porque memorável) - mais intenso e imediato será o seu efeito.

Assim, nos termos de Conte (1996, p. 35):

a alusão ocorrerá como um ato literário se uma vibração concordante puder ser estabelecida entre as memórias do poeta e do leitor quando elas estiverem direcionadas para uma fonte já armazenada em ambos. [...] Uma única palavra no novo poema será muitas vezes suficiente para condensar uma inteira situação poética e reavivar o seu ânimo.

A alusão caminha a par da categoria das palavras ambivalentes, aquelas que carregam dois, ou mais, sentidos, o novo e o que já possuíam no(s) texto(s) e contexto(s) anteriores. Temos, assim, uma função semelhante à da figura, como propõe Conte. E, como figura do discurso poético, a alusão serve à construção da obra literária em seus vários gêneros e nas várias formas em que a imitação (como a entendemos) pode se processar: a estilização, a paráfrase e a paródia, processos em que, numa definição bastante simples, podemos dizer, com Affonso Romano de Sant'Anna (2001, p. 41), "a paródia deforma, a paráfrase conforma e a estilização reforma."

Dizemos "bastante simples" porque o processo de imitação é bem mais complexo do que isso, quanto mais o que envolve a construção do texto como montagem de fragmentos, em que cada fragmento pode indiferentemente estilizar, parafrasear ou parodiar o fragmento que evoca e, ainda assim, ser o texto no seu todo - ou na sua arquitextualidade - uma paródia, uma paráfrase ou uma estilização (SILVA, 2009, p. 60).

Bakhtin (por meio de Kristeva) dá ao termo imitação o sentido que a paráfrase apresenta em Sant'Anna (2001, p. 27-28): "a paráfrase, repousando sobre o idêntico e o semelhante, pouco faz evoluir a linguagem”, ou seja, é repetição.

A estilização se aproxima da emulação, que relativiza, mas não fere o sentido do texto anterior: "na estilização não ocorre uma 'traição' à organização ideológica do sistema como ocorreria na paródia, onde há uma perversão do sentido original" (SANT'ANNA, 2001, p. 39). 
Contudo, havemos de considerar que nenhum desses processos é neutro. Retomando Paulo Sérgio de Vasconcellos, lembramos que "a operação intertextual [...] sempre cria novos sentidos que se sobrepõem ou contrastam com o original reproduzido ou evocado" (2001, p. 38-39) e são tantas as formas de se tratar o "material "tomado emprestado"' que, nos termos de Vasconcellos, "nem sequer podem ser catalogadas de modo esquemático [...], pois as possibilidades do jogo intertextual são virtualmente ilimitadas" (2001, p. 38-39).

Tendo tudo isso em vista, todas essas teorias e toda uma nomenclatura própria para esse tipo de análise esclarecida, passamos às obras de Ariosto e Sá de Miranda que se prestam à análise comparativa.

Primeiramente, tomamos a obra cômica mirandina e ariostea como produto de um contexto histórico-literário específico, de uma tradição literária em que o imitar era a regra. Esses poetas têm como intenção primeira ao compor esse tipo de obra inserir-se em uma tradição literária que não só aceita como pressupõe a alusão a textos precedentes, ou seja, uma tradição literária em que as relações intertextuais se dão de maneira consciente e técnica.

A apropriação, que é a ação de tomar um texto anterior, incorporá-lo a um texto novo e torná-lo próprio pelo novo sentido que ele adquire dentro do novo contexto em que se insere, ocorre nos dois autores. ${ }^{4}$

A alusão e a apropriação, em poesia culta, ocorrem sempre de maneira intencional, e é parte da dinâmica do processo da imitatio. A alusão é o principal dos artifícios do imitador, do doctus imitator, que, naturalmente, lança mão também de outros recursos na construção de sua obra.

Nas comédias, por exemplo, os trocadilhos e jogos de palavra, em geral, são bastante usados para atingir-se o cômico. Hipérboles, anáforas, metáforas e um sem número de figuras podem enriquecer o texto, mas é a alusão que, ao fazer referência a outro texto, ativa o jogo intertextual praticado em poesia douta.

O meio mais comum e mais simples de se aludir a outro texto é a citação literal, e não necessariamente entre aspas: é a reprodução de versos inteiros ou de trechos de versos, que se supõe serão reconhecidos pelo leitor culto.

A citação é o meio de aludir mais usado por Ariosto. Em Sá de Miranda podemos observar que as alusões se dão mais por paráfrases, na maior parte do texto escrito em

\footnotetext{
${ }^{4}$ Lembremos que o texto do qual se apropria pode ser um anterior do mesmo autor, quando se dá o que chamamos de auto-alusão, ou autocitação.
} 
português. As citações propriamente ditas são empregadas em latim, quando um personagem diz alguma sententia latina, algum provérbio ou expressão latina.

No entanto, Sá de Miranda segue de perto - ou tenta seguir - o processo de composição utilizado por Ariosto, que foi o primeiro poeta da Idade Moderna a usar a fôrma clássica na composição de textos inéditos. Sua primeira comédia, La Cassaria, data de $1508 .^{5}$

E Sá de Miranda foi o primeiro poeta português a fazer uso dos modelos clássicos, que trouxe de sua longa temporada na Itália, onde esteve em contato com Ariosto e com tantos outros poetas da época.

Pode-se observar tanto nos textos mirandinos como nos de Ariosto que a paráfrase, em geral, condensa falas (ou versos) do texto original, especialmente porque 0 modelo latino, que é originalmente composto em versos, é reproduzido em prosa pelos escritores renascentistas.

A "condensação", termo empregado por Vasconcellos, é outro meio pelo qual a alusão evoca outro(s) texto(s). Trata-se da fusão de duas metades de versos diferentes, numa "espécie de contaminatio em miniatura", ${ }^{6}$ como observou Vasconcellos (2001) a respeito da composição da Eneida.

Ariosto usou desse meio muitas vezes para evocar, ao mesmo tempo, dois textos diferentes, e usou-o tantas vezes num mesmo texto que denominamos esse fenômeno de "supercontaminação" (SILVA, 2009).

Sá de Miranda usou a contaminatio para evocar vários textos e contextos diferentes, mas muito pouco para aludir a diferentes versos ou partes de versos.

Em La Cassaria, por exemplo, Ariosto baseia seu argumento não só em temas e motivos de várias comédias latinas, mas também nos da literatura italiana, como os tomados às novelas do Decamerão, de Boccaccio. Ele constrói sua comédia como montagem de fragmentos, como "mosaico de citações" provenientes de 18 peças de Plauto e de todas as 6 de Terêncio. São cento e cinco citações contando somente as das comédias latinas.

Quanto a Sá de Miranda, observamos que ele tenta arduamente imitar os antigos imitando Ariosto. A fonte dele não está na Antiguidade, mas no poeta italiano, seu

\footnotetext{
${ }^{5}$ O poeta já traduzia, antes disso, textos de Plauto e Terêncio, fazendo-os representar na corte de Ferrara.

${ }^{6}$ A contaminatio é uma técnica de criação literária que consiste em misturar dois ou mais textos modelares para obter um texto inédito. Utilizada, principalmente, pelos comediógrafos latinos, pode ser observada também em outros gêneros. No proêmio da Eneida, por exemplo, temos um exemplo de contaminatio - ver VASCONCELLOS, op. cit., p. 112-124.
} 
contemporâneo. É Ariosto quem Ihe mostra o caminho das fontes, como demonstraremos mais à frente.

Vimos já que o processo de recriação poética que os romanos antigos denominaram imitatio envolve o emprego pelo poeta de fórmulas e convenções próprias de cada gênero por ele retomado e também o empréstimo de partes de textos - que podem variar no tamanho -, de temas e de conteúdos, que, com um novo arranjo e em um novo contexto, virão a compor um texto inédito.

A liberdade poética fica, assim, limitada, mas a imitatio não impede que o poeta seja criativo e pratique o jogo alusivo engenhosamente. Ele pode criar artifícios para driblar as limitações do processo e as restrições impostas por cada gênero em particular, reelaborando criativamente o modelo.

Vimos ainda que, para tornar próprio um texto que retoma e para fazer de sua imitação uma imitação bem sucedida, o poeta precisa aprofundar-se no universo de significações do texto imitado, trazendo essas significações para o texto novo. A essas significações somam-se os sentidos que a mudança de contexto e as modificações aplicadas ao modelo geram.

O poeta pode brincar com as alusões, recriando o modelo de diversos modos, mas a imitação bem sucedida supõe o reconhecimento pelo leitor de todo esse processo de apropriação, supõe que o leitor tome parte no jogo alusivo, relacionando a obra literária com a(s) outra(s) obra(s) literária(s) que ela evoca e percebendo os sentidos gerados pelo diálogo intertextual, porque é com a sua participação que o processo alusivo se completa.

Sabemos também que, de diversos modos, o poeta consegue escapar às restrições do gênero. Por meio de modificações ou de rearranjo dos lugares-comuns próprios do modelo, ou ainda por meio da introdução no modelo de ideias que normalmente não são a ele vinculadas, o poeta pode mostrar-se inovador.

Todos esses artifícios foram usados pelos poetas do Renascimento italiano e podem ser observados em suas composições, especialmente no que diz respeito à arquitextualidade, que é a relação intertextual mais facilmente percebida por um leitor não tão erudito, pois não implica o reconhecimento de textos específicos ou a percepção de sutilezas alusivas, senão o reconhecimento de um gênero ou de seus lugares-comuns.

É nesse aspecto do processo criativo que se verificam as maiores inovações. Ariosto introduziu no gênero novos temas, novos tipos, criou novos lugares-comuns, novos tipos, todos tomados da realidade que o circundava. E, como ele, também Maquiavel e Bibbiena o fizeram, para citar somente os nomes mais relevantes, seguindo 
suas pegadas. Juntou todas essas novidades aos temas, aos tipos e a tudo mais que era próprio do gênero antigo, que lhe servira de mote para a criação de novos textos.

Além disso, Ariosto acrescentou ao rol de modelos exemplares textos da sua própria tradição literária, como fez com Bocaccio, e esses textos lhe forneceram mais temas e mais matéria para ser usada na prática alusiva.

Quanto à herança clássica que Sá de Miranda recebeu, observamos que ela passa primeiro pelas mãos dos poetas renascentistas italianos, que lhe imprimem a sua marca e Ihe agregam valores. Assim, o poeta português torna-se um herdeiro mais rico, que também vai tentar deixar sua marca para a posteridade.

A primeira comédia mirandina, Os Estrangeiros, tem por modelo, principalmente, I Suppositi, de Ariosto, onde o poeta vai buscar o motivo da jovem que é prometida em casamento a um homem mais velho e bem estabelecido na vida - o tipo "doutor", criado por Ariosto. O problema é que esta jovem encontra-se apaixonada por um rapaz de sua idade, que the corresponde a paixão. Existe, porém, ainda um outro impedimento que torna a relação entre os dois jovens impossível, como é comum a grande parte da comédia latina. Na comédia, as coisas começam mal, para depois acabarem bem.

A segunda comédia, Os Vilhalpandos, cujo motivo da mãe alcoviteira, que vende os "favores" da filha, a princípio, parece ter sido inspirado diretamente na Asinaria, de Plauto, muito provavelmente foi inspirado em La Lena, de Ariosto. O poeta retoma o tipo lena da Asinaria e recria a alcoviteira, não como mãe, mas como preceptora da jovem que deseja corromper. Nossa hipótese pode-se confirmar pela observação de que Sá de Miranda se apropria de outros elementos do método de composição e do próprio produto da recriação de Ariosto. Lembremos que ele já havia extraído o tema de sua primeira comédia de I Suppositi e já havia se apropriado do tipo "doutor" de Ariosto. Toma do italiano também o modelo de composição em prosa, a amarração de fragmentos provenientes de comédias diversas, entremeados de alusões a assuntos locais e contemporâneos, somados à crítica aos costumes e, em especial, à corrupção entre os membros da Igreja.

A comédia Os Vilhalpandos é claramente inspirada em La Lena, e, pelos motivos que acima expostos, entende-se que Sá de Miranda chegou ao texto original de Plauto levado pelas mãos de Ariosto. Pela tradução do texto original da Asinaria, em latim, e pela observação da recriação que dela fez Ariosto, é possível afirmarmos que os trechos que remetem à Asinaria, retomados por Sá de Miranda, foram traduzidos e citados, quase sempre, literalmente do texto latino. Mas nossa conclusão é a de que o poeta português 
recorre à comédia plautina depois de passar pela ariostea. Ele vai sempre buscar as fontes de Ariosto para, então, escrever suas comédias.

Admitimos que Sá de Miranda buscou exercitar sua criatividade e buscou também imprimir inovações ao modelo, a começar pela tentativa de aperfeiçoar o tipo "doutor" de Ariosto - no que é bem sucedido, a nosso ver. Ele apresenta um novo tema - o dos estrangeiros - e faz pequenas alterações em outros, amplia o defeito de um tipo, diminui o de outro, fazendo que eles sirvam aos seus propósitos moralizantes. E, ainda, introduz no modelo clássico um elemento da tradição portuguesa: as esparsas do capitão Vilhalpando, que são um tipo de poeminha bem próprio da realidade mirandina.

Todas as inovações referentes à arquitextualidade de suas comédias parecem ter tido êxito. Mas é quando Sá de Miranda tenta construir o seu texto seguindo o modo de compor de Ariosto, como "mosaico de citações", que se perde em meio ao excesso de contaminação, e o diálogo intertextual resulta comprometido pela falta de sentidos. $\mathrm{O}$ saldo final da obra faz lembrar o exemplo que dá Horácio, no início da Epístola aos Pisões, do pintor que mistura elementos díspares para compor uma figura única e acaba por criar uma espécie de monstro.

\section{Considerações finais}

Se a finalidade do jogo alusivo é gerar novos sentidos pela evocação de textos e contextos anteriores e não simplesmente adornar um texto novo com citações de outros textos, Sá de Miranda não obteve êxito. Talvez o poeta tenha realmente tomado a empresa de compor comédias regulares como exercício intelectual - como se tem afirmado sempre -, sem a preocupação de contribuir com inovações para o enriquecimento da "arte alusiva". Talvez nem tenha tido essa pretensão.

A nosso ver, como já dissemos alhures, o valor literário da comédia ariostea supera em muito a da comédia mirandina. Ariosto soube engenhosamente usar a arte alusiva, enquanto Sá de Miranda, tentando aproximar-se do modo que Ariosto se apropriava de textos alheios, deixou muito a desejar no que diz respeito tanto ao engenho quanto à arte.

Mas havemos de reconhecer o valor da comédia mirandina, que, não tendo relevo artístico, tem a seu favor o fato inegável de ser iniciadora de um gênero e de um movimento artístico em Portugal. E há nela também outro valor, que é o de refletir no texto a imagem do mundo de seu tempo, valor histórico e documental de uma época. 


\section{Referências}

ARISTÓFANES, Comedias (Los caballeros, La paz, Las avispas, Pluto). Valencia: Prometeo, [s.d.]. (Tomo segundo).

BONANNO, Maria Grazia, L'allusione necessaria. Roma: Ateneo, 1990.

ECO, Umberto. Interpretação e Superinterpretação. São Paulo: Martins Fontes, 2005.

EDMUNDS, Lowell. Intertextuality and the reading of Roman poetry.Baltimore: Johns Hopkings University Press, 2001.

GENETTE, Gérard. Palimpsestes - la literature au sécond degré. Paris: Seuil, 1982.

KRISTEVA, Julia. Introdução à semanálise. São Paulo: Perspectiva, 1974.

PASQUALI, Giorgio. "Arte Allusiva”. In: Stravaganze - Quarte e Supreme. Venezia: Neri Pozza, 1951.

RUSSELL, D. A. De imitatione. In: WEST, David \& WOODMAN, Tony (editors). Creative imitation and Latin Literature. Cambridge: Cambridge University Press, 1979.

SANT'ANNA, Affonso Romano de. Paródia, paráfrase \& Cia. 7. ed. São Paulo: Ática, 2001.

SILVA, Martha F. Maldonado Baena da. A Comédia Clássica de Sá de Miranda e o diálogo intertextual com seus paradigmas literários. João Pessoa: Editora Universitária da UFPB, 2009.

VASCONCELLOS, Paulo Sérgio. Efeitos intertextuais na Eneida de Virgílio. São Paulo: Humanitas, 2002. 